\title{
Comparison of different meat tenderization methods: a review
}

\author{
${ }^{1}$ Woinue, Y., ${ }^{1}$ Ayele, A., ${ }^{1}$ Hailu, M. and ${ }^{2, *}$ Chaurasiya, R.S. \\ ${ }^{I}$ Department of Life Science, School of Basic Science and Research, Sharda University, Greater Noida, \\ Gautam Buddh Nagar, Uttar Pradesh - 201306, India \\ ${ }^{2}$ Department of Biotechnology, School of Engineering and Technology, Sharda University, Greater Noida, \\ Gautam Buddh Nagar, Uttar Pradesh - 201306, India
}

\begin{abstract}
Article history:
Received: 1 July 2019

Received in revised form: 7

August 2019

Accepted: 12 August 2019

Available Online: 30 August 2019
\end{abstract}

\section{Keywords:}

Bromelain,

Enzymatic methods,

Meat,

Palatability,

Papain,

Tenderization

DOI:

https://doi.org/10.26656/fr.2017.4(3).239

\begin{abstract}
Meat tenderness is one of the quality parameters that affect the tough muscle and changes into soft meat, which is characterized by, increased the palatability, juiciness, and flavor of the meat, the process is known as meat tenderization. According to literature reports, meat can be tenderized by using different methods. The tenderize meat gives rise to customer satisfaction and repeated buyers that improve the value of the meat industry as well as the restaurants. The most widely used methods for tenderization of meat are mechanical, electrical stimulation, application of exogenous proteolytic enzyme, and thermal treatment methods. All these methods result in tenderization of meat that reduces the cooking times, hardness of meat and chewiness of meat products, that can increase meatiness, flavor, and overall palatability. Therefore, an attempt has been made to review the different meat tenderization methods concerning their effectiveness, economic value, and mode of action. The toughness of the meat is reduced during mechanical method by disrupting the structure of the meat and weakening the protein network in muscles. Whereas, in case of enzymatic treatment tenderization is achieved by hydrolyzing the meat protein, which reduces the bonding between muscles and results in softening of the meat.
\end{abstract}

\section{Introduction}

The quality of meat is multi-dimensional concept where the value of meat and meat products are determined based on different factors such as ethical and social (organic vs. conventional and animal welfare), symbolic and cultural (religion, e.g. pork or beef vs. lamb; halal vs. non-halal), nutritional (health aspects), organoleptic (texture, flavor and color) and functionality (table cuts vs. processing) (Miller et al., 2001; Neethling et al., 2017). Organoleptic (sensory) quality plays a significant role regarding marketability basis while others become more important once the meat is cooked such as flavor and tenderness. After the slaughter of the animal, rigor mortis shorten muscle protein fibers causing the meat to become tough. After $48 \mathrm{hrs}$ of rigor mortis, biochemical changes take place in the meat that results in tender or soft meat that satisfies the need of the consumer, and the process is called tenderization. One of the fundamental problems facing the meat industry is tenderness of meat and meat product aspect to quality basis (Koohmaraie, 1996). It is arguably qualities characteristic which affecting consumer satisfaction and positive perception of meat. Among the meat quality parameters, tenderness and juiciness are the most important characteristics (Risvik, 1994; Kuypers and Kurth, 1995; Wood et al., 1995; Ergezer and Gokce, 2011). There are two primary components of skeletal muscle which determines the tenderness of the meat. The one is contractile tissue, which is mainly the myofibrillar fraction, and the other is connective tissue fraction, which determines the fixed or "background toughness" (Tarrant, 1998). The onset of rigor mortis causes myofibrillar toughness in the carcass and enzymatic break down contractile protein contractile proteins in post slaughtered meat muscles causes tenderization of the meat (Naveena et al., 2011). By their specific behavior, collagen, the main constituent of perimysium, and the myofibrillar system are the main substances responsible for the hardness modifications observed in the cooking of meat (Dransfield, 1977; Lepetit et al., 2000; Purslow, 2005; Jacques Lepetit, 2008). However, many authors attribute to connective tissue proteins, particularly those in the perimysium, a significant role in meat texture (Lepetit and Culioli, 1994; Kuypers and Kurth, 1995; Purslow, 2005; Jacques 
Lepetit, 2008). To evaluating tenderness, sensory analysis is one of the standard method and its replaced by instrumental measurement of mechanical properties Among this device Warner-Bratzle is used to measure fiber shear resistance, while texture profile analysis (TPA) provides functional correlations with sensorial descriptors (Szczesniak et al., 1963; Purchas et al., 2004; De Huidobro et al., 2005). A variety of chemical, physical and mechanical methods have been introduced for tenderizing meat. All these methods have advantages and disadvantages based on their effect on meat during tenderization. Traditional aging relies on endogenous protease, and its effectiveness varies between animals slaughtering and its time for consumption (Koohmaraie, 1994).

The present study aimed at evaluating the effects of different methods (mechanical, chemical, and enzymatic) on the meat tenderization. Physical and chemical methods have been developed for assessing tenderness of the meat. Physical methods include penetrating, biting, measuring force for shearing, stretching, mincing, and compressing. Those chemical methods have evolved the determination of connective tissue, its solubility (Mahendrakar et al., 1989) and enzymatic digestion.

The objective of this review is to add knowledge of the different way of tenderization of meat and meat product that plays an essential role in the meat industry, in restaurants and as well as tenderization of meat using at home in daily life.

\section{Meat tenderization}

Meat quality is defined by those traits that consumer perceives as desirable which includes both visual and sensory apart from safety, health and more intangible traits such as 'clean' and 'green' or welfare status of the production system. There are several quality parameters of meat among which tenderness is the most critical organoleptic characteristics of meat that defined as the toughness and resistance to cut. Meat tenderness is the most difficult to predict, but it is essential for meat quality and consumer acceptance, and it is referred to mechanical properties of meat which related to the strength of the structural components of the muscle fiber such as the myofibrillar mass, sarcoplasmic proteins, and connective tissue, that is evaluated by instrumental method and sensory (Kerry et al., 2002). On the other hand, toughness resulted from different factors that affect the structural components of muscle by the opposing action of tenderization. The toughness of meat is due to various factors when the animal alive, such as chronological age, genetic factor, and feeding management and the second one is after slaughtering of the animal due to the stiffness of muscle known as rigor mortis. Meat tenderness depends on different factors such as type of tissue, postmortem $\mathrm{pH}$, and temperature (Anderson et al., 2012). The tenderness of meat can be measured by in general into two ways these are physical methods such as measuring of force for shearing, penetration, biting, mincing, stretching and compressing the chemical method of measuring tenderness are the determination of connective tissue, its solubility and enzymatic digestion. Conventional methods for tenderization includes modified chilling, extended aging, altered carcass suspension, and pre-rigor skeletal separations are not sufficient to guarantee tenderness. The meat tenderization is also performed by mechanical, enzymatic, electrical, thermal method, etc. which have been discussed in this review. The review mainly focuses on the effect of meat tenderization methods on improving the quality of meat and to enhancing the customer acceptability by providing customer satisfaction and increase the meat industry marketing.

\section{Methods of meat tenderization}

\subsection{Mechanical tenderization}

Mechanical tenderization by applying a set of needle or blades has been one of the technique for a long time with the first patent granted for a blade tenderization prototype at the start of the $20^{\text {th }}$ century (Jamison, 1907). Mechanical tenderization of meat and meat products are practicable in Northern America (Gill et al., 2013) and Europe (Tyszkiewicz and Jakubiec-Puka, 1995), it involves accepted technique of blade or needle piercing pounding, compressing and extrusion to improve the tenderness of meat products (Pietrasik and Shand, 2004) and enhancing the consumer palatability (Brooks et al., 2000). This blade or needle makes to break up the tissue or muscle fiber into shorter segments, that results in the connective tissue leads to the release of myofibrillar proteins. The mechanical method of tenderization gives rise to the tenderness of beef muscle fiber by disrupting the structure of the meat and causing a weakening in the meat protein network that results in the extraction of protein that can solubilize during cooking of meat (Motycka and Bechtel, 1983). Many studies reported that mechanical tenderization could reduce cooking time, hardness, and chewiness of meat and meat products (Jeremiah et al., 1999; Shackelford et al., 1989).

Mechanical tenderization is a vital part of commercial beef processing and based on the tenderness of meat consumers preference for the quality and overall palatability and flavor of meat products; this method is widely accepted in the hotel, restaurants, and distribution trade rather than in meat industry (Miller, 1975). 


\subsection{Electrical stimulation method of meat tenderization}

Electrical stimulation is one of the methods of changing tough muscle to soften by passing an electric current through the body or carcass of the freshly slaughtered animal. It is a proper application of high voltage electrical stimulation will prevent the cold shortening in leaner carcasses and consequently improve meat tenderness. The tendering effects of electrical stimulation will depend on several factors, such as the intensity of the stimulation process as depicted in the input electrical parameters, total electric input during processing $\mathrm{pH}$-temperature profile, and post-mortem temperature. Given that several electrical stimulation processing regimes are used worldwide (Devine et al., 2004) and many factors will be involved, such as chilling rate and carcass size, it is difficult to have a set of parameters that have general use. However, it is much easier to point out the factors that reduce the efficacy of electrical stimulation. Electrical stimulation can reduce the aging time of carcass by speed up the post mortem change of the carcass (Strydom et al., 2005). During slaughtering use of electrical stunning of animals immediately before slaughter, the muscles are positively affected by tenderness mainly through mechanically fracturing of the gait, intermediate and shorter muscle fiber of meat. Electrical stimulation of carcasses is applied mostly to prevent excessive muscle contraction during the onset of rigor mortis as a result of rapid chilling (cold-shortening). This phenomenon may occur when the muscle temperature drops below $10^{\circ} \mathrm{C}$ while the muscles still contain sufficient energy (at $\mathrm{pH}>6.0$ ) to drive contraction. By applying the cold temperature immediately after slaughtering makes the sarcoplasmic reticulum and mitochondria to retain calcium, which increases the concentration of calcium in the sarcoma and muscle fiber contraction that enhances the toughness (Simmons et al., 2008). Electrical stimulation is well known that in the form of an electric current leads to fast post-mortem glycolysis rates and consequently, to an accelerated $\mathrm{pH}$ decline. Therefore electrical stimulation has been provided in the meat industry to perform fast chilling conditions without side-effect on the excessive muscle contraction.

\subsection{Enzymatic method}

Enzymes are biological catalysts that increases the rate of reactions by reducing the reactions activation energy, the absence of undergoing any well-ordered change in their structures at the end of a reaction. When the enzyme is pure, the reaction occurs at a much higher rate, and the enzyme itself is not consumed in the activity (Bodansky and Rose, 1922). Initially, in the nineteenth century, the enzymes were recognized as a proteolytically active constituent in the latex of tropical papaya fruit. According to many studies, the structure of myosin and actin filaments is affected by the plant protease. There are five exogenous plant proteases such as papain, bromelain, ficin, and proteases from Aspergillus oryzae and Bacillus subtilis and can break down the protein in muscle and hydrolyze collagen and elastin which helps in meat tenderization (Rawdkuen et al., 2013). Ketnawa et al. (2010), reported that collagen of beef muscle and giant catfish skin is degraded by bromelain proteolytic enzyme that derived from pineapple and also according to Qihe et al. (2006) studies high concentrations of plant protease can cause meat deformation. During the aging, primarily an enzymatic degradation by proteolytic enzymes in meat are responsible for tenderization. However, when more tenderization is necessary, the plant or microbial enzymes can be exogenously added (Lantto et al., 2009). The meat tenderization is achieved by using proteolytic enzymes such as papain, ficin, and bromelain exogenously at a commercial level for meat tenderization (Gokoglu et al., 2017; Barekat and Soltanizadeh, 2018). A proteolytic enzyme derived from ginger rhizome and fruits of Cucumis trigonous Roxb plants are also used for meat tenderization (Garg and Mendiratta, 2006; AbdelNaeem and Mohamed, 2016).

According to the Illanes (2008) report, the proteolytic enzymes such as papain, bromelain and ficin are not the only use in meat tenderization but also these are the essential aspect to economic values, these enzymes were accounted for approximately $5 \%$ of the global sales of commercial proteases in 2008. Papain (EC 3.4.22.2) bromelain (EC 3.4.22.3.2) and ficin (EC 3.4.22.3) are the well-known plant cysteine proteases used in different industries such as food processing, pharmaceutics and other industries

The present review will focus on mechanical, physical, and exogenous enzymatic methods used to improve the tenderness of intact meat cuts.

\subsubsection{Papain}

Papain is a vital plant proteolytic enzyme which is derived from the latex of papaya fruit. Initially, the latex is obtained by scoring and followed by drying and known as the crude material. The aqueous extracts of Carica papaya latex contain some cysteine proteinases that can be separated by ion-exchange chromatography, and fully active for can be obtained by covalent chromatography using thiol-disulfide exchange (Baines and Brocklehurst, 1979; Brocklehurst et al., 1981; Baines and Brocklehurst, 1982; Mellor et al., 1993). The matured papaya fruit naturally loses their functions of a proteolytic enzyme, to achieve robust and dynamic 
papain should better to use from the immature and green papaya fruit. Papain is regarded as natural proteolytic enzymes, which could break off the lycine, phenylalanine, and arginine peptide bond in the muscle protein upon tenderization mechanism (Menard et al., 1990).

\subsubsection{Bromelain}

Bromelain can be extracted from the waste peel, core, and stem fruit of the Bromeliaceae or pineapple family, mostly from Ananascomosus Merr., sp. (Kelly, 1996; Chaurasiya and Hebbar, 2013). Bromelain has a proteolytic enzyme of papain can breakdown myofibrillar proteins and collagen and causes tenderness in meat Different studies reported that bromelain and papain were found useful on duck (Buyukyavuz, 2014), beef (Chaurasiya et al., 2015; Ionescu et al., 2008; Istrati et al., 2012), fish (Feng et al., 2017), pork and chicken (Ketnawa et al, 2012). Bromelain, in general, produces a better flavor than papain (Kim and Taub, 1991). Papain causes the formation of a mushy texture and off-flavors (Stefanek et al., 2002).

\subsubsection{Ficin}

A plant protease called Ficin is used in meat tenderization (Marques et al., 2010), and also it is important as an enhancer of the solubility of muscle proteins (Ramezani et al., 2003). Ficin (E 3.4.22.3) is a class of cysteine (with thiol function group) or sulfhydryl protease from the genus Ficus. Different studies show that the latex of Ficus glabrata and Ficus carica contains cysteine endopeptidases and the crude extracted ficin have been the protease enzymes. At the temperature range of 45 to $55^{\circ} \mathrm{C}$ within a $\mathrm{pH}$ range of 5 to 8 can obtain the maximum activity of ficin, and it requires cysteine or other reducing agents for activation. The enzymes have broad specificity with the acceptance of hydrophobic amino acid residues.

\subsubsection{Microbial enzymes}

Proteolytic activity containing bacterial strains play an important role in the meat tenderization process by the degradation of meat proteins (Bekhit, 2010). The $B$. subtilis species contains two major proteases, subtilisin, and neutral protease. This bacterial strains approved by the US Food and Drug Administration (FDA). The bacterial proteases have become a popular choice because of their higher specific activity and low inactivation temperature. The Alkalophilic bacillus specious, which produces the enzyme alkaline elastase, can have the ability to break down the myofibrillar proteins, collagen, and elastin in tenderized meat. The $\mathrm{pH}$ of alkaline elastase 5.5-6.0 and the temperature range $10-50^{\circ} \mathrm{C}$ and also the. Comparing the bacterial proteases in myofibrillar protein is lower than the plant protease; however, the collagen degradation by hydrolysis activity of bacterial proteases was found to be intermediate to hydrolytic actions of papain and bromelain from $A$. oryzae (Yeh et al., 2002) are commercially available bacterial proteases reported that the proteases stable over a wide range $\mathrm{pH}$ and below $70^{\circ} \mathrm{C}$. These bacteria produce Aspartic proteases and show the optimal activity at $\mathrm{pH}$ range $2.5-6.0$ and $75^{\circ} \mathrm{C}$; its activity is reduced by 20\% (Ashie et al., 2002).

\subsection{Thermal treatment method}

Thermal treatment is one of the most important ways to change the components of muscle that control toughness. The major components include myofibrillar proteins and the connective tissue proteins, collagen, and elastin. The cooking at a high temperature can denature the protein that results in structural changes in the meat such as the destruction of cell membranes, shrinkage of meat fibers, shrinkage and solubilization of the connective tissue, aggregation and gel formation of myofibrillar and sarcoplasmic proteins (Tornberg, 2005). Temperature and cooking time have a large effect on the physical properties of meat and eating quality. At higher temperatures, water is expelled from meat, accompanied by denaturation of actin, indicating a strong correlation.

\section{Conclusion}

There are various methods of treatments available for meat tenderization. Meat tenderness is mainly associated with palatability and consumer satisfaction. The effectiveness of each technique varies depending on the type of muscle, and the technology advancement contributes to the improvement of the methods. Meat industry encounters critical challenges at all stages, starting from slaughtering to consumption. Technological interventions like use of exogenous enzymes (like papain, bromelain, and ficin), mechanical or blade tenderization, electrical stimulation, and thermal method which are currently applied in the meat industry are effective in improving tenderness.

\section{Reference}

Abdel-Naeem, H.H. and Mohamed, H.M. (2016). Improving the physico-chemical and sensory characteristics of camel meat burger patties using ginger extract and papain. Meat Science, 118, 52-60. https://doi.org/10.1016/j.meatsci.2016.03.021

Anderson, M., Lonergan, S., Fedler, C., Prusa, K., Binning, J. and Huff-Lonergan, E. (2012). Profile of biochemical traits influencing tenderness of muscles from the beef round. Meat Science, 91(3), 247-254. 
https://doi.org/10.1016/j.meatsci.2012.01.022

Ashie, I., Sorensen, T. and Nielsen, P. (2002). Effects of papain and a microbial enzyme on meat proteins and beef tenderness. Journal of Food Science, 67(6), 2138-2142. https://doi.org/10.1111/j.13652621.2002.tb09516.x

Baines, B.S. and Brocklehurst, K. (1979). A necessary modification to the preparation of papain from any high-quality latex of Carica papaya and evidence for the structural integrity of the enzyme produced by traditional methods. Biochemical Journal, 177(2), 541-548. https://doi.org/10.1042/bj1770541

Baines, B.S. and Brocklehurst, K. (1982). Isolation and characterization of the four major cysteineproteinase components of the latex of Carica papaya L. reactivity characteristics towards 2, 2'-dipyridyl disulfide of the thiol groups of papain, chymopapain A and B, and papaya peptidase A. Journal of Protein Chemistry, 1(2), 119-139. https://doi.org/10.1007/ BF01025635

Barekat, S. and Soltanizadeh, N. (2018). Effects of ultrasound on microstructure and enzyme penetration in beef longissimus lumborum muscle. Food and Bioprocess Technology, 11(3), 680-693. https:// doi.org/10.1007/s11947-017-2043-8

Bekhit, A.E.-D.A. (2010). Fish Roe: Fermentation Encyclopedia of Biotechnology in Agriculture and Food, p. 251-256. USA: CRC Press. https:// doi.org/10.1081/E-EBAF-120045417

Bodansky, M. and Rose, W.C. (1922). Comparative Studies of Digestion: I. The Digestive Enzymes of Coelenterates. American Journal of PhysiologyLegacy Content, 62(3), 473-481. https:// doi.org/10.1152/ajplegacy.1922.62.3.473

Brocklehurst, K., Baines, B. and Kierstan, M. (1981). Papain and other constituents of Carica papaya L. Top. Enzyme and Fermentation Biotechnology, 5, 232-235.

Brooks, J., Belew, J., Griffin, D., Gwartney, B., Hale, D., Henning, W., Reagan, J. and Savell, J.W. (2000). National beef tenderness survey-1998. Journal of Animal Science, 78(7), 1852-1860. https:// doi.org/10.2527/2000.7871852x

Buyukyavuz, A. (2014). Effect of bromelain on duck breast meat tenderization.

Chaurasiya, R., Sakhare, P.Z., Bhaskar, N. and Hebbar, H.U. (2015). Efficacy of reverse micellar extracted fruit bromelain in meat tenderization. Journal of Food Science and Technology, 52(6), 3870-3880. https://doi.org/10.1007/s13197-014-1454-z

Chaurasiya, R.S. and Hebbar, H.U. (2013). Extraction of bromelain from pineapple core and purification by
RME and precipitation methods. Separation and Purification Technology, 111, 90-97. https:// doi.org/10.1016/j.seppur.2013.03.029

De Huidobro, F.R., Miguel, E., Blázquez, B. and Onega, E. (2005). A comparison between two methods (Warner-Bratzler and texture profile analysis) for testing either raw meat or cooked meat. Meat Science, 69(3), 527-536. https://doi.org/10.1016/ j.meatsci.2004.09.008

Devine, C., Hopkins, D., Hwang, I., Ferguson, D. and Richards, I. (2004). Electrical stimulation. In Jensen, W., Devine, C. and Dikeman, M. (Eds.) Encyclopedia of meat sciences., p. 413-423. USA: Elsevier. https://doi.org/10.1016/B0-12-464970X/00198-7

Dransfield, E. (1977). Intramuscular composition and texture of beef muscles. Journal of the Science of Food and Agriculture, 28(9), 833-842. https:// doi.org/10.1002/jsfa.2740280910

Ergezer, H. and Gokce, R. (2011). Comparison of marinating with two different types of marinade on some quality and sensory characteristics of Turkey breast meat. Journal of Animal and Veterinary Advances, 10(1), 60-67. https://doi.org/10.3923/ javaa.2011.60.67

Feng, X., Zhu, Y., Liu, Q., Lai, S. and Yang, H. (2017). Effects of bromelain tenderisation on myofibrillar proteins, texture and flavour of fish balls prepared from golden pomfret. Food and Bioprocess Technology, 10(10), 1918-1930. https:// doi.org/10.1007/s11947-017-1963-7

Garg, V. and Mendiratta, S. (2006). Studies on tenderization and preparation of enrobed pork chunks in microwave oven. Meat Science, 74(4), 718 -726. https://doi.org/10.1016/j.meatsci.2006.06.003

Gill, C., Yang, X., Uttaro, B., Badoni, M. and Liu, T. (2013). Effects on survival of Escherichia coli O157: $\mathrm{H} 7$ in non-intact steaks of the frequency of turning over steaks during grilling. Journal of Food Research, 2(5), 77-89. https://doi.org/10.5539/ jfr.v2n5p77

Gokoglu, N., Yerlikaya, P., Ucak, I. and Yatmaz, H.A. (2017). Effect of bromelain and papain enzymes addition on physicochemical and textural properties of squid (Loligo vulgaris). Journal of Food Measurement and Characterization, 11(1), 347-353. https://doi.org/10.1007/s11694-016-9403-3

Illanes, A. (2008). Enzyme biocatalysis. Principles and Applications. New York, USA: Springer-Verlag New York Inc. https://doi.org/10.1007/978-1-40208361-7 
Ionescu, A., Aprodu, I. and Pascaru, G. (2008). Effect of Papain and Bromelin on Muscle and Collagen Proteins in Beef Meat. Annals of the University Dunarea de Jos of Galati Fascicle VI--Food Technology, 1(31).

Istrati, D., Vizireanu, C., Dima, F. and Dinica, R. (2012). Effect of marination with proteolytic enzymes on quality of beef muscle. Scientific Study and Research. Chemistry and Chemical Engineering, Biotechnology, Food Industry, 13(1), 81.

Jamison, F. C. (1907). Meat tenderer. US Patents No. $863,717$.

Jeremiah, L., Gibson, L. and Cunningham, B. (1999). The influence of mechanical tenderization on the palatability of certain bovine muscles. Food Research International, 32(8), 585-591. https:// doi.org/10.1016/S0963-9969(99)00134-9

Kelly, G.S. (1996). Bromelain: a literature review and discussion of its therapeutic applications. Alternative Medicine Review, 1(4), 243-257

Kerry, J.P., Kerry, J.F. and Ledward, D. (2002). Meat processing: improving quality. USA: Elsevier. https://doi.org/10.1201/9781439823163

Ketnawa, S., Chaiwut, P. and Rawdkuen, S. (2012). Pineapple wastes: A potential source for bromelain extraction. Food and Bioproducts Processing, 90(3), 385-391. https://doi.org/10.1016/j.fbp.2011.12.006

Ketnawa, S., Rawdkuen, S. and Chaiwut, P. (2010). Two phase partitioning and collagen hydrolysis of bromelain from pineapple peel cultivar. Biochemical Engineering Journal, 52(2), 205-211. https:// doi.org/10.1016/j.bej.2010.08.012

Kim, H.-J. and Taub, I.A. (1991). Specific degradation of myosin in meat by bromelain. Food Chemistry, 40 (3), 337-343. https://doi.org/10.1016/0308-8146(91) 90117-7

Koohmaraie, M. (1994). Muscle proteinases and meat aging. Meat Science, 36(1-2), 93-104. https:// doi.org/10.1016/0309-1740(94)90036-1

Koohmaraie, M. (1996). Biochemical factors regulating the toughening and tenderization processes of meat. Meat Science, 43, 193-201. https:// doi.org/10.1016/0309-1740(96)00065-4

Kuypers, R. and Kurth, L.B. (1995). Collagen's contribution to meat texture. Paper presented at the Meat'95: [proceedings of] the Australian Meat Industry Research Conference: CSIRO Meat Industry Research Conference. Gold Coast, Queensland, Australia: CSIRO Division of Food Science and Technology.

Lantto, R., Kruus, K., Puolanne, E., Honkapää, K., Roininen, K. and Buchert, J. (2009). Enzymes in meat processing. In Whitehurst, R.J. and van Oort, M. (Ed.) Enzymes in Food Technology, $2^{\text {nd }}$ ed. USA: Blackwell Publishing. https:// doi.org/10.1002/9781444309935.ch12

Lepetit, J. (2008). Collagen contribution to meat toughness: Theoretical aspects. Meat Science, 80(4), 960-967.

https://doi.org/10.1016/ j.meatsci.2008.06.016

Lepetit, J. and Culioli, J. (1994). Mechanical properties of meat. Meat Science, 36(1-2), 203-237. https:// doi.org/10.1016/0309-1740(94)90042-6

Lepetit, J., Grajales, A. and Favier, R. (2000). Modelling the effect of sarcomere length on collagen thermal shortening in cooked meat: consequence on meat toughness. Meat Science, 54(3), 239-250. https:// doi.org/10.1016/S0309-1740(99)00086-8

Mahendrakar, N., Dani, N., Ramesh, B. and Amla, B. (1989). Studies on influence of age of sheep and post -mortem carcass conditioning treatments on muscular collagen content and its thermolability. Journal of Food Science and Technology, 26(2), 102 -105 .

Marques, A.Y.C., Maróstica, M.R. and Pastore, G.M. (2010). Some nutritional, technological and environmental advances in the use of enzymes in meat products. Enzyme Research, 2010, 1-8. https:// doi.org/10.4061/2010/480923

Mellor, G.W., Thomas, E., Topham, C. and Brocklehurst, K. (1993). Ionization characteristics of the Cys-25/His-159 interactive system and of the modulatory group of papain: resolution of ambiguity by electronic perturbation of the quasi-2mercaptopyridine leaving group in a new pyrimidyl disulphide reactivity probe. Biochemical Journal, 290(1), 289-296. https://doi.org/10.1042/bj2900289

Menard, R., Khouri, H.E., Plouffe, C., Dupras, R., Ripoll, D., Vernet, T. and Storer, A.C. (1990). A protein engineering study of the role of aspartate 158 in the catalytic mechanism of papain. Biochemistry, 29(28), 6706-6713. https://doi.org/10.1021/ bi00480a021

Miller, M., Carr, M., Ramsey, C., Crockett, K. and Hoover, L. (2001). Consumer thresholds for establishing the value of beef tenderness. Journal of Animal Science, 79(12), 3062-3068. https:// doi.org/10.2527/2001.79123062x

Miller, S. (1975). Mechanical tenderization of meat in the HRI trade. $28^{\text {th }}$ Annual Reciprocal Meat Conference of the America Meat Science Association, 1975. Retrieved from website: https:// meatscience.org/docs/default-source/publications- 
resources/rmc/1975/mechanical-tenderization-ofmeat-in-the-hri-trade.pdf?sfvrsn=eb08bbb3 2

Motycka, R.R. and Bechtel, P.J. (1983). Influence of prerigor processing, mechanical tenderization, tumbling method and processing time on the quality and yield of ham. Journal of Food Science, 48(5), 1532-1536. https://doi.org/10.1111/j.1365-2621.1983.tb03531.x

Naveena, B., Kiran, M., Reddy, K.S., Ramakrishna, C., Vaithiyanathan, S. and Devatkal, S.K. (2011). Effect of ammonium hydroxide on ultrastructure and tenderness of buffalo meat. Meat Science, 88(4), 727 -732. https://doi.org/10.1016/j.meatsci.2011.03.005

Neethling, N.E., Suman, S.P., Sigge, G.O., Hoffman, L.C.and Hunt, M.C. (2017). Exogenous and endogenous factors influencing color of fresh meat from ungulates. Meat and Muscle Biology, 1(1), 253275. https://doi.org/10.22175/mmb2017.06.0032

Pietrasik, Z. and Shand, P. (2004). Effect of blade tenderization and tumbling time on the processing characteristics and tenderness of injected cooked roast beef. Meat Science, 66(4), 871-879. https:// doi.org/10.1016/j.meatsci.2003.08.009

Purchas, R., Rutherfurd, S., Pearce, P., Vather, R. and Wilkinson, B. (2004). Cooking temperature effects on the forms of iron and levels of several other compounds in beef semitendinosus muscle. Meat Science, 68(2), 201-207. https://doi.org/10.1016/ j.meatsci.2004.02.018

Purslow, P.P. (2005). Intramuscular connective tissue and its role in meat quality. Meat science, 70(3), 435 -447. https://doi.org/10.1016/j.meatsci.2004.06.028

Qihe, C., Guoqing, H., Yingchun, J. and Hui, N. (2006). Effects of elastase from a Bacillus strain on the tenderization of beef meat. Food Chemistry, 98(4), 624-629.

j.foodchem.2005.06.043

Ramezani, R., Aminlari, M. and Fallahi, H. (2003). Effect of chemically modified soy proteins and ficintenderized meat on the quality attributes of sausage. Journal of Food Science, 68(1), 85-88. https:// doi.org/10.1111/j.1365-2621.2003.tb14119.x

Rawdkuen, S., Jaimakreu, M. and Benjakul, S. (2013). Physicochemical properties and tenderness of meat samples using proteolytic extract from Calotropis procera latex. Food Chemistry, 136(2), 909-916. https://doi.org/10.1016/j.foodchem.2012.08.077

Risvik, E. (1994). Sensory properties and preferences. Meat Science, 36(1-2), 67-77. https:// doi.org/10.1016/0309-1740(94)90034-5

Shackelford, S., Reagan, J., Mann, T., Lyon, C. and Miller, M. (1989). Effects of blade tenderization, vacuum massage time and salt level on chemical, textural and sensory characteristics of precooked chuck roasts. Journal of Food Science, 54(4), 843845.

2621.1989.tb07895.x

Simmons, N., Daly, C., Cummings, T., Morgan, S., Johnson, N. and Lombard, A. (2008). Reassessing the principles of electrical stimulation. Meat Science, 80(1), 110-122. https://doi.org/10.1016/ j.meatsci.2008.05.006

Stefanek, J., Scanga, J., Belk, K. and Smith, G. (2002). Effects of enzymes on beef tenderness and palatability traits. p. 61-66. USA: Colorado State University Animal Science, Department of Animal Science.

Strydom, P., Frylinck, L. and Smith, M. (2005). Should electrical stimulation be applied when cold shortening is not a risk? Meat Science, 70(4), 733742. https://doi.org/10.1016/j.meatsci.2005.03.010

Szczesniak, A.S., Brandt, M.A. and Friedman, H.H. (1963). Development of standard rating scales for mechanical parameters of texture and correlation between the objective and the sensory methods of texture evaluation. Journal of Food Science, 28(4), 397-403.

https://doi.org/10.1016/ j.meatsci.2005.03.010

Tarrant, P. (1998). Some recent advances and future priorities in research for the meat industry. Meat Science, 49, S1-S16. https://doi.org/10.1016/S03091740(98)90035-3

Tornberg, E. (2005). Effects of heat on meat proteinsImplications on structure and quality of meat products. Meat Science, 70(3), 493-508. https:// doi.org/10.1016/j.meatsci.2004.11.021

Tyszkiewicz, I. and Jakubiec-Puka, A. (1995). Ultrastructure of mechanically tenderised pork muscle. Meat Science, 41(3), 273-282. https:// doi.org/10.1016/0309-1740(94)00004-Q

Wood, J., Nute, G., Fursey, G. and Cuthbertson, A. (1995). The effect of cooking conditions on the eating quality of pork. Meat Science, 40(2), 127-135. https://doi.org/10.1016/0309-1740(94)00051-8

Yeh, C.-M., Yang, M.-C. and Tsai, Y.-C. (2002). Application potency of engineered G159 mutants on $\mathrm{P} 1$ substrate pocket of subtilisin $\mathrm{YaB}$ as improved meat tenderizers. Journal of Agricultural and Food Chemistry, 50(21), 6199-6204. https:// doi.org/10.1021/jf0256889 